\title{
Om te floreer: Die viering van die Eucharistie en Seligman se teorie van welstand
}

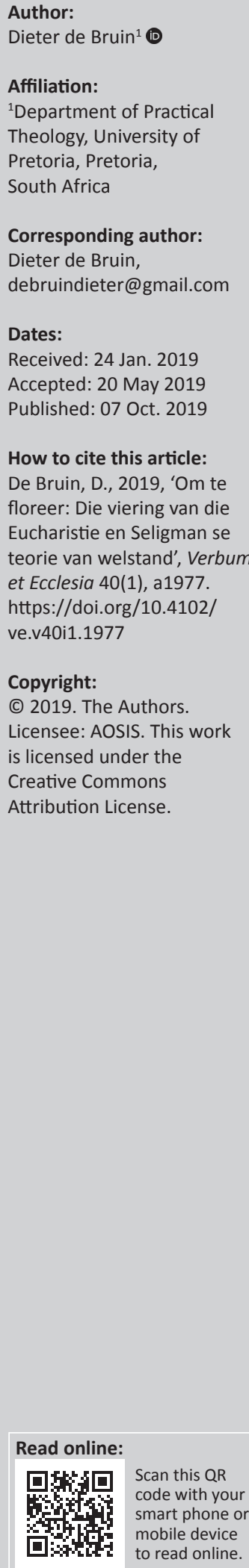

To thrive: The celebration of the Eucharist and Seligman's theory of well-being. Human flourishing is a growing topic of research in various disciplines, including theology and liturgical studies. In this article the Dutch Reformed Church's official theology of the Eucharist was drawn into conversation with Martin Seligman's theory of human flourishing. This was done by juxtaposing Seligman's five pillars of well-being to the Dutch Reformed Church's formularies for the celebration of the Eucharist. The conversation is also enriched by snippets of wisdom from other psychologists, philosophers and theologians. The encounter between Seligman's theory and one version of the Church's theology of the Eucharist delivered fruitful connections and avenues for further exploration in the understanding and enhancement of human flourishing.

Interdisciplinary and/or interdisciplinary implications: The research includes the following disciplines: Practical Theology, Philosophical Theology and Psychology. This article is fundamentally interdisciplinary as it is structured as a conversation between Theology and Psychology to be mutually enriching in service of human flourishing.

Keywords: positive psychology; human flourishing; Eucharist/Lord's Supper; virtues; alimentary theology.

\section{Inleiding}

Martin Seligman dek die tafel van sy boek Flourish (2011:Kindle-uitgawe, plekmerker 147) met 'n belofte: 'This book will help you flourish'.

Die (ietwat minder ambisieuse) belofte wat hierdie artikel maak, is dat die viering van die Eucharistie ruim moontlikheid bied om lewensvolheid (soos wat dit deur Seligman gekonseptualiseer word) te bevorder.

Beloftes maak skuld. Soos Karen Scheib (2014) Seligman se vyf pilare van welstand gebruik om in gesprek te gaan met die feministiese narratiewe teologie aangaande menslike florering, gebruik ek Seligman se teorie om die moontlikhede uit te lig wat die viering van die Eucharistie bied om menslike florering te bevorder.

Die Eucharistie is 'n maaltyd en ek sluit aan by die teologiese benadering en metodologie vir hierdie refleksie by Montoya (2009, plekmerker 124) se 'alimentêre teologie': '... theology's vocation is to become alimentation: theology not ony concerned about food matters, but also theology envisioned as food' (my klem). Meer spesifiek sluit ek ook aan by Montoya wat sy teologiese benadering sien as 'n gesamentlike en interdissiplinêre geleentheid om brood te breek wat voedsaam sal wees vir die gemeenskap (plekmerker 193).

In die gees van Montoya word in hierdie artikel 'brood gebreek' in 'n interdissiplinêre gesprek tussen Martin Seligman se teorie oor menslike florering en die Nederduitse Gereformeerde Kerk (NG) Kerk se teologie van die nagmaal. ${ }^{1}$

Die maaltyd wat ek in die artikel voorsit, bestaan uit drie gange:

- As voorgereg word Seligman se teorie van florering as 'n oliebol voorgesit, met my eie opvatting van lewensvolheid as 'n vulsel vir die holte van die deegkring.

- As hoofgereg word die Positiewe Sielkunde se verstaan van die vyf pilare van welsyn in gesprek met die viering van die Eucharistie gebring in 'n smörgasbord van teologiese en sielkundige invalshoeke.

1.Dit is egter nie die enigste gesprek nie, en sal nie al die behoeftes vervul nie. Daar is nie ruimte om ' $n$ uitgewerkte teologie van die nagmaal op die tafel te plaas nie, maar daar word hoofsaaklik aangesluit by die amptelike liturgie van die NG Kerk se teologie van die nagmaal soos dit vervat word in die Handleiding vir die erediens. 
- Nagereg is 'n klein soetigheid van die voorlopige afleiding oor die viering van die Eucharistie en menslike florering deur die lens van Seligman se teorie.

\section{Seligman se teorie van florering (sonder'n sentrum)}

Seligman (2002) het aanvanklik in sy boek Authentic happiness aangevoer dat geluk uit drie dimensies bestaan, naamlik 'positive emotions, engagement and meaning' (Seligman 2002:Kindle-uitgawe, plekmerker 284). In sy boek Flourish (2011:Kindle-uitgawe, plekmerker 309) het Seligman se teorie egter 'n fokusverskuiwing ondergaan. Aanvanklik het hy die onderwerp van die Positiewe Sielkunde as 'geluk' gesien, en dat die standaard om geluk te meet, lewenstevredenheid sou wees, en dat die doel van die positiewe sielkunde sou wees om lewenstevredenheid te bevorder. Hy het egter tot die insig gekom dat die onderwerp van die positiewe sielkunde welstand moet wees, en dat die standaard om welstand te meet, florering moet wees, en dat die doel van die positiewe sielkunde moet wees om florering te bevorder.

Vir Seligman is welstand 'n konstruk en nie 'n entiteit op sigself nie. Hy gebruik die analogie om te verduidelik: Die weer is nie 'n 'ding op sigself' nie, maar dit bestaan uit verskillende aspekte soos die temperatuur en humiditeit wat wel dinge op sigself is. Op dieselfde manier is welstand 'n konstruk wat nie op sigself meetbaar is nie, maar dit bestaan uit 'werklike dinge' wat wel gemeet kan word (Seligman 2011:Kindle-uitgawe, plekmerker 345-352).

Die elemente wat die konstruk van welstand konstitueer, is volgens Seligman (2011:Kindle-uitgawe, plekmerker 364-442):

- positiewe emosie

- meelewendheid

- positiewe verhoudings

- betekenis

- prestasie

\section{Kritiek op Seligman se teorie en voorveronderstellings}

Om Seligman te nooi as gespreksgenoot vir die teologiese gesprek rakende florering is nie bo kritiek verhef nie (bv. Beier 2014; Nyengele 2014). Ek wil in die artikel nie die meriete van Seligman se teorie bevraagteken nie, maar in die gees van wedersydse verryking (Charry 2011:185) van sy insigte gebruik maak in nadenke oor hoe die weeklikse viering van die Eucharistie kan bydra tot menslike florering.

Die onderwerp van die Positiewe Sielkunde, aldus Seligman (2011:Kindle-uitgawe, plekmerker 309), is welstand en die doel van Positiewe Sielkunde om menslike florering te vermeerder deur positiewe emosie, betekenis en positiewe verhoudings.

Die feit dat Seligman nie 'n definisie van florering as sodanig gee nie, is egter wel iets wat ter wille van die argument hier genoem moet word. Seligman se konsep van die konstruk kan egter ook gesien word as 'n 'oliebol sonder 'n sentrum' (Sundararajan 2005:54 in Hackney 2007:214) waar '... the notion of an objective universal human telos separate from expressions of personal preference is typically denied, ignored, or given fairly superficial lip service...'.

In ooreenstemming met Milbank (2006:382) glo ek die teologie kan hierdie leë sentrum vul.

Ek werk met drie teologiese aannames:

- Eerstens dat die volheid van die lewe gevind word in die deelname aan die lewe van God (Ward 2015:1011).

- Tweedens dat in die deelname aan die Eucharistie mense (en die kosmos) deelneem aan die lewe van God (Caldecott 2012:197).

- Derdens dat die deelname aan die Drie-enige God se lewe nie net ' $n$ 'transendente' belewing bo of buite hierdie lewe het nie, maar dat dit ook 'n rol speel in die immanente van die lewe. Vanuit'n feministiese narratiewe perspektief (sien Scheib 2014:1-2) is die Positiewe Sielkunde 'n bondgenoot deurdat die Positiewe Sielkunde, soos die Feministiese Teologie, 'n alternatiewe storie bied oor die volheid van die lewe wat ook in hierdie lewe gevind word.

Die belewing van vreugde in God én in 'hierdie' lewe is waarmee ons gesprek begin.

\section{Positiewe emosie en die genesing van affek in die Eucharistie}

Seligman (2011:Kindle-uitgawe, plekmerker 280-289) beskryf die konsep van positiewe emosies so: 'What we feel: pleasure, rapture, ecstacy, warmth, comfort, and the like. An entire life led successfully around this element, I call the "pleasant life".'

In 'n artikel getiteld 'Salvation: The pedagogy of affect' bring Graham Ward (2015:1000) positiewe emosie met redding op sigself in verband. Hy verstaan verlossing as die beweging na 'n lewe wat getuig van meer positiewe as negatiewe affek; en sonde as dit wat verkentering tot negatiewe affek veroorsaak. Dit is hierdie verslawing wat skade aan ons doen en vermeerder deur eindelose siklusse van om teen gesondig te word en om teen ander te sondig. Dit is van dié gebondenheid waarvan verlossing ons red (Ward 2015:1009).

Ward bespreek die sosiale, kognitiewe en liggaamlike aspekte van negatiewe emosies, asook die nuanses tussen gevoel, emosie en affek, en daarop brei ek nie hier uit nie, behalwe om saam met Ward te beklemtoon dat negatiewe affek die hele menslike bestaan raak. In die geheel, aldus Ward (2015:1003), is die effek van negatiewe gevoelens om ons te verkleineer en ons kapasiteit vir positiewe emosies en positiewe affek soos verwondering, geluk en kalmte te verminder.

Aan die ander kant is daar positiewe emosies wat meer fundamenteel is as beleefde negatiewe emosies. Hy argumenteer dat vir 'n Christen daar sekere positiewe 
emosies soos vreugde, vrede, liefde, vergifnis en deernis is wat meer fundamenteel is as die evaring van negatiewe affek soos vrees, of positiewe affek soos geluk. Die rede daarvoor, volgens Ward (2015), is dat hierdie oer-affekte eerstens goddelik is, alvorens hulle menslik sou wees:

These are, if you will, Trinitarian 'affects'; 'affects' circulating within the nature of the Godhead in which, en Christo, Christians participate. If 'affects' here, with the impassibility of God, are within inverted commas, that is because we know them only by analogy. (p. 1009)

In 'n teologiese gesprek met die Positiewe Sielkunde sou mens kon sê dat dit waar is, wat Peterson (2013) na aanleiding van Seligman en Csikszentmihalyi (2000) aanvoer, dat wat goed in die lewe is, net so eg is as dit wat sleg is: 'not derivative, secondary, epiphenomenal, illusory, or otherwise suspect' (Peterson 2013:Kindle-uitgawe, plekmerker 181). Hierdie 'metafisiese' uitspraak van Peterson kan teologies begrond word in die onaandoenlikheid van God self en dat daar nog dieper 'positiewe' affekte is wat tradisionele positiewe emosies transendeer. Ward (2015:1009) verduidelik verder deur te sê dat positiewe affek dit is wat deur God self geniet word in God se eie trinitêre lewe en gemeenskap met God self.

Die beweging van sonde wat tot negatiewe affek lei, na 'n lewe van meer fundamentele positiewe affek wat in God gesetel is as die proses van redding, vind volgens Ward nie plaas deur goddelike fiat nie, maar deur emosionele regimes wat ons sensoriese en kognitiewe response verander. Hierdie transformasie gebeur nie volgens goddelike fiat nie; maar eerder deur goddelike inwerking in die konteks van dissipelskap wat 'n tranformasie, of selfs 'transubstansiasie' van 'n hart van klip na 'n hart van vlees, deur beide goddelike en menslike handeling, bewerk word (Ward 2015:1003).

Die suggestie van die transsubstansiasie van die hart kan reeds vir ons 'n aanduiding wees dat die Eucharistie so 'n 'emosionele regime' kan wees wat ons sensoriese en kognitiewe reaksies op die wêreld kan vorm. Ten minste op die vlak van formele betekenis kan mens waarskynlik hierdie aanname maak.

Enersyds koppel Die handleiding van die erediens (NG Kerk 2010) die viering van die Eucharistie aan die verlossing van sonde:

Hierdeur waarborg Hy sy soenverdienste vir ons so volledig asof ons self voor God gestaan het, self die straf vir ons sonde gedra het, self daarvoor gesterf en opgestaan het en ons geregtigheid voor God verwerf het. (bl. 97)

Interessant genoeg word emosies in hierdie dimensie van die betekenis van die nagmaal gerelativeer:

Die sekerheid wat hierdie waarborg ons gee, is nie gegrond op ons gevoelens op stemminge nie, maar op die tekens uit die hand van die Here, dit is in die Here self gevestig. (bl. 97)

Die emosies word nie hier genoem nie, maar daar sou goedskiks gedink kon word aan die gebrek aan vrede, die emosie van skaamte en vrees wat Ward (2015:1001) ook spesifiek in sy artikel noem.

Die Eucharistie word ook gekoppel aan die positiewe emosie van vreugde: 'Die nagmaal is ' $n$ vreugdefees in die midde van én teenoor die vreugdeloosheid van hierdie wêreld' (oorspronklike klem). Andersyds kry dit ook 'transendentale' bevestiging: 'In die nagmaalsfees mag die gemeente nou van die vreugde smaak wat vir ons wag by die bruilofsmaaltyd van die Lam' (NG Kerk 2010:99). As sonde dan op hierdie affektiewe manier verstaan kan word, dan kan dit dalk wees dat brood wat gebreek en wyn wat gedrink word 'tot volkome verlossing van al jou sonde' (NG Kerk 2010:92) ook beteken dat hierdie brood en wyn tot jou genesing sal dien - ook jou affektiewe genesing.

\section{'n Lewe van positiewe verhoudings en die viering van die Eucharistie}

Verhoudings met mense is vir die Positiewe Sielkunde onontbeerlik: positiewe sielkundiges se studies benadruk keer op keer die belang van ander mense. As sosiale wesens, sou dit nie verrassend wees dat mense so sterk in die sielkunde se goeie lewe figureer nie, aldus Peterson (2013:Kindle-uitgawe, plekmerker 1532). Peterson, Isaacowitz, Vaillant en Seligman (2003:181-201) meen dat die kapasiteit om lief te hê en liefde te ontvang die nouste verband hou met die belewenis van subjektiewe welstand op tagtigjarige leeftyd.

Die Positiewe Sielkunde plaas liefde as 'n sterk punt van karakter wat uitgedruk word in versorgende wedersydse verhoudings met ander en dit sluit in romantiese liefde, vriendskap, liefde tussen ouers en hul kinders, asook ander sosiale verbintenisse soos byvoorbeeld die verhouding tussen kollegas (Scheib 2014:9).

In haar bespreking van Seligman se pilaar van 'positiewe verhoudings' sluit Scheib (2014) aan by positiewe sielkundiges se navorsing oor liefde en in haar refleksie bied sy haar eie gedagtes oor liefde in aansluiting by Oord (2010:17) se definisie: 'To love is to act intentionally, in sympathetic/empathic response to God and others, to promote overall well-being'.

Vir Von Balthasar (2004) is die viering van die Eucharistie 'n kontemplasie van liefde in liefde en dit is vanuit hierdie liefdevolle viering waarvan die kerk uitgestuur word om lief te hê:

... the celebration of the Eucharist is itself an anamnesis, which
means that it is contemplation in love and the communion of
love with love; and it is only from such a celebration that a
Christian mission goes out into the world ... (Kindle-uitgawe,
plekmerker 975)

Ook vanuit 'n gereformeerde perspektief kan dit beklemtoon word dat dit vir Calvyn waar is dat die deelname aan die 
liggaam van Christus noodwendig 'n deelname in liefde beteken. Volgens Billings (2007:15-16) beteken vir Calvyn om aan Christus deel te neem, altyd die dankbare vervulling van die wet van die liefde, deur die krag van die Gees. Hierdie deelname vind plaas binne die konteks van die kerk en die kerk se sakramentele lewe. Die liefde kring uit van wedersydse liefde in die kerk, tot die liefde vir die naaste, en uiteindelik liefde wat openbaar word deur geregtigheid en billikheid in die samelewing.

Hierdie gedagte word ook mooi verwoord in die eredienshandleiding van die NG Kerk (2010):

Die Nagmaal is die viering van die gemeenskap met die lewende Here en met mekaar ... Dit sluit ook gemeenskap met mekaar as lidmate van die een liggaam van Christus in aangesien dieselfde Gees wat ons oë vir Christus oopmaak, ook ons oë vir mekaar oopmaak en ons in liefde met mekaar verbind. (bl. 98)

Een van die navorsers binne die kader van die Positiewe Sielkunde by wie Scheib aansluit, is Barbara Fredrickson (2013). Hoewel Fredrickson haar eie perspektief op die konsep van die liefde het, kan dit op 'n transversale wyse aansluit by die deug van liefde soos wat dit in die konteks van positiewe emosies hierbo geskets is. Ek kan nie hier volledig op Fredrickson (2013) se teorie ingaan nie en ek volstaan by haar eie opsomming van die gevolgtrekkings uit haar navorsing:

To put it in a nutshell, love is the momentary upwelling of three tightly interwoven events: first, a sharing of one or more positive emotions between you and another; second, a synchrony between your and the other person's biochemistry and behaviors; and third, a reflected motive to invest in each other's well-being that brings mutual care. (p. 17)

Fredrickson se teorie is dat 'liefde' soos wat sy beskryf, nie noodwendig net hoef plaas te vind tussen 'geliefdes' nie, maar dat dit ' $\mathrm{n}$ momentele gebeurtenis is wat ook tussen vreemdelinge kan plaasvind (2013:15-17). Ek wil nie volledig teologies oor hierdie siening van Fredrickson reflekteer nie, maar ek sien dat dit tog 'n uitnodiging kan wees om te reflekteer oor hoe die viering van die Eucharistie 'n geleentheid kan wees wanneer daar deur liturgiese handelinge daarop gefokus kan word om mense die geleentheid te gee om saam positiewe emosies soos vreugde en verligting te beleef. Daar kan ook met gekoördineerde handelinge in ritme en resonansie bymekaar gekom word. Daarbenewens kan daar ook binne die raamwerk van die prediking, liturgie en sorg van die gemeente (al is dit net vir die uur en 'n bietjie op 'n Sondag) 'n belegging in mekaar se welstand gemaak word en kan mense op so 'n wyse ook 'n toename in die belewenis van volheid ondervind.

Tydens die nagmaal in baie gemeentes en tradisies word die vredegroet met mekaar gedeel - daar is ruim geleentheid om mekaar in die oë te kyk en fisiek in kontak met mekaar te kom. Soos die maaltyd wat gedeel word, kan hierdie oomblikke ook 'n ikoon of 'n templaat word wat al ons ander praktyke van groet informeer. Soos wat ons mekaar, in die konteks van die nagmaal, as die beeld van Christus sien in die erediens, kan elke interaksie met ' $n$ mens en situasie dien as 'n geleentheid om liefde te beleef en liefde te bewys.

Soos Wainwright (2014) dit stel:

The Lord's Supper is the rite in which the love of the Lord Jesus is demonstrated and experienced, whereby the virtue of love may be inculcated among the immediate recipients and even extended beyond them through their corresponding conduct. (Kindle-uitgawe, plekmerker 474)

Die Eucharistie is inderdaad in die woorde van pous Benedictus die 16de die Sacramentum caritatis (Benedict XVI 2007).

\section{Die betekenisvolle lewe en die Eucharistie}

Seligman (2011:Kindle-uitgawe, plekmerker 302) karakteriseer die betekenisvolle lewe soos volg: 'The Meaningful Life consists in belonging to and serving something bigger than the self ...'.

Om die nagmaal te verstaan as 'n offer kan 'n moontlikheid bied om te verstaan hoe die Eucharistie 'n lewe van betekenis kan bevorder. Sonder om in die besonderhede van hierdie kontroversiële dimensie van die Eucharistie in gereformeerde kringe in te gaan, vind ek die ireniese opsommende aanbeveling van Hunsinger (2008) van hulp:

It is proposed ... that the consecrated elements of bread and wine be seen not only in their 'downward' movement (or 'humanward') significance as the means of communion, but also in their 'upward' (or 'Godward') significance as the means by which church is incorporated into Christ's offering of himself in eternal intercession on behalf of the faithful and the world. (p. 317)

Een dimensie in die soeke na betekenis wat my tref in Scruton (2014:2) is die feit dat hy by die filosoof Patočka aansluit wat aanvoer dat die betekenis van die lewe, selfs in die 'goddelose' twintigste eeu, te vinde is in dit waarvoor mens jou lewe sal offer.

Scruton (2014:2) volg Durkheim deur te sê dat die kernreligieuse ervaring die ervaring is om ' $n$ lidmaat (member) van iets groters te wees, en waar ek opgeroep word om my eie belange op te offer ter wille van die groep en om my lidmaatskap van die groep te vier in handelinge van toewyding wat geen ander regverdiging sou hê as dat dit beveel word nie. Die nagmaaldiens dien by uitstek as antwoord op die vraag na behoort en diens aan iets groters (NG Kerk 2010):

In die nagmaal word ons gekonfronteer met die vrae: waarop sit jy jou hart? Waar lê jou hoogste prioriteite en lojaliteite? Wie roep jy aan in jou oomblikke van nood? Op wie vertrou jy? Want dié een wat ons as die bron van alle goed beskou en wat in tye van verdriet en moeilikheid ons enigste toevlug is, dié dinge waarop 'n mens se hart staatmaak en waarop dit geheel en al vertrou, is in werklikheid jou God. (bl. 98) 


\section{'n Lewe wat vloei - die deugdelike lewe en die Eucharistie}

'n Kernelement van Seligman se welstand-teorie is wat hy noem engagement (Kindle-uitgawe, plekmerker 285-297).

Hierdie dimensie sluit veral by Csikszentmihalyi (1992) se bekende konsep van vloei aan (Kindle-uitgawe, plekmerker 4283-4524). Seligman (2011:Kindle-uitgawe, plekmerker 290) beskryf hierdie dimensie soos volg: 'Being one with the music, time stopping, and the loss of self-consciousness during an absorbing activity ...'. Wat uiters belangrik vir my bespreking hier is, is wat Seligman (2011:295) sê oor die weg na vloei: 'There are no shortcuts to flow. On the contrary, you need to deploy your highest strengths and talents to meet the world in flow'.

In Seligman se aanvanklike teorie het hy die rol van sterk punte en die deugde gekoppel aan die dimensie van vloei, maar met sy welstand-teorie het hy die rol van die deugde en sterk punte verhef as onderliggend aan al vyf van die pilare van welstand. Niemiec en Wedding (2014) voer aan dat:

... Positive strengths of character are viewed by many as the backbone of positive psychology because the most central areas of our well-being (e.g., relationships, flow, success, meaning, and positive emotions) are enabled by good character. (bl. 9)

Dit kan wees dat die viering van die Eucharistie die tipe karakter kan kultiveer wat die dimensies van Seligman se konstruk van welstand kan fasiliteer. En as mens oor die kweek van karakter dink in 'n teologiese konteks, sal die deugde-etiek 'n natuurlike gespreksgenoot wees.

In die breë gesproke is daar in die deugde-etiek vier dimensies wat gehanteer word in die vorming van karakter (Van Buskirk 2012:122).

Die eerste eienskap is ' $n$ telos - dit verwys daarna dat daar in die deugde-etiek 'n fundamentele oriëntasie tot die hoogste goed of doel van alles is. Tweedens beklemtoon die deugdeetiek die rol wat gemeenskap speel in die vorming van karakter en in die tradisionele Griekse deugde-etiek is hierdie gemeenskap die polis wat deel in 'n gemeenskaplike telos waaraan die gemeenskap gebind word. Derdens word die rol van praktyke binne die gemeenskap beklemtoon waardeur karakter gevorm word. Vierdens is dít wat gevorm word, deugsaamheid of arete.

Ek maak gebruik van Van Buskirk (2012) se uiteensetting van hierdie dimensies om 'n gesprek oor die Eucharistie se vorming van karakter met die Positiewe Sielkunde te fasiliteer.

\section{Telos}

Telos gaan vir die deugde-etiek oor die bereiking van 'n sekere doelwit. Die bydrae wat die teologie hier kan maak, is om 'n meer robuuste beskrywing van die telos van die deugde te gee. Die aard van die telos kan op verskillende maniere beskryf word, maar hier word aangesluit by die Thomistiese benadering om God sien '... as object of the bliss of all the blessed ...' (Westberg 2015:Kindle-uitgawe, plekmerker 391). Die Eucharistie kan die deelnemers telkens weer na dié telos oriënteer en op 'n manier ook aan hierdie telos laat deelneem.

\section{Polis}

Die tweede aspek wat die deugde-etiek beklemtoon, is die gemeenskapgeoriënteerde rol rakende 'n gedeelde telos, naamlik om karakter te vorm. Een van die dimensies wat die Positiewe Sielkunde bestudeer, is positiewe instellings (Peterson 2013:Kindle-uitgawe, plekmerker 1530-2869), wat goeie karakter moontlik maak. In Lopez en Snyder (2011:383459) se handboek word die instellings van die familie, skole, instellings vir tersiêre onderrig en regs- en regeringsinstellings bespreek. Sakeondernemings, gemeenskappe en samelewings word ook as voorbeelde van positiewe instellings genoem.

Dit sou beslis ook moontlik wees om die kerk as een van hierdie positiewe instellings te sien. Een van die belangrikste aspekte waaroor gereflekteer kan word, is juis die rol wat die Eucharistie speel in die konstituering van die kerk (McPartlan 1993).

\section{Areté}

Die deugde speel 'n deurslaggewende rol in die Positiewe Sielkunde (met my klem):

Our project supports the premise of positive psychology that attention to good character sheds light on what makes life worth living. As Aristotle proposed long ago, happiness is the purpose of life, and living in accordance with one's virtues is how to achieve happiness. (Peterson \& Park 2011:32)

Hier is ongelukkig nie ruimte om genoeg aandag te gee aan Peterson en Seligman (2004) se projek om die sterk punte van karakter te identifiseer nie, maar vir die doeleindes van die gesprek kan hier weereens net 'n paar kursoriese notas gemaak word om aan te dui hoe die kontoere van 'n voortgaande gesprek kan lyk.

Vir Peterson en Seligman (2004:12-13) bestaan die komponente van 'n goeie karakter uit verskillende vlakke. Hul klassifikasiesisteem is nie net horisontaal van aard nie, maar ook vertikaal. Daar is vir hulle drie vlakke van konseptuele abstraksie. (Ek fokus hier op deugde en goeie karaktertrekke; die ander vlak is situasionele temas wat bekendheid ook in die Suid-Afrikaanse konteks verwerf het as die Clifton StrengthsFinder [Gallup s.a] waaraan ek nie aandag gee nie.)

Deugde is vir Peterson en Seligman (2004:13) sleuteleienskappe wat deur morele filosowe en godsdienstige denkers geïdentifiseer is. Die deugde wat die outeurs identifiseer, is wysheid, moed, menslikheid, geregtigheid, matigheid en transendensie.

Peterson en Seligman (2004:33-52) het wat hulle noem die ses belangrikste deugde geïdentifiseer deur na kulturele en 
godsdienstige tradisies te kyk wat volgens hulle die grootste impak op die menslike samelewing gehad het, en hulle het hulself nog verder beperk tot die geskrewe tekste vanuit hierdie kulture. Hulle het, onder meer, ook na die Christelike tradisie gekyk en hulle sluit spesifiek aan by die deugde wat Aquino in aansluiting by Plato geïdentifiseer het. Peterson en Seligman (2004) maak dié opmerking:

Note that within the Seven Heavenly Virtues Aquinas enumerated what we believe are the six core virtues: He presents the four cardinal virtues by name, invokes transcendence with the virtues of faith and hope, and humanity with the virtue of charity. (bl. 48$)^{2}$

Goeie karaktertrekke is die sielkundige bestanddele, die prosesse of meganismes wat die deugde definieer: '... they are distinguishable routes to displaying one or another of the virtues' (Peterson \& Seligman 2004:14). Dit is op hierdie vlak van klassifikasie wat Peterson en Seligman (2004) fokus in hul handboek. Collicutt (2015:58) voer aan dat die groot wins van die raamwerk van goeie karaktertrekke, van die VIA- (Values in Action) raamwerk, die woordeskat is wat dit moontlik maak om oor menslike sterk punte te praat en om hulle na te vors.

Daar sou navorsing gedoen kon word op elk van hierdie 24 sterk punte se interaksie met die viering van die Eucharistie, maar ek reflekteer slegs kortliks, op 'n illustratiewe manier op hoe om spesifiek deur die lens van Peterson se sterk punte die viering van die Eucharistie te verryk.

Vir die doeleinde van die gesprek fokus ek op die karaktertrek van dankbaarheid wat deur Peterson en Seligman (2004) gedefinieer word:

Gratitude is a sense of thankfulness and joy in response to receiving a gift, whether the gift be a tangible benefit from a specific other or a moment of peaceful bliss evoked by natural beauty. (bl. 554)

Die viering van die Eucharistie impliseer selfs in naam dat dit 'n 'fees van dankbaarheid' (NG Kerk 2010:89) is. Interessant genoeg verwys Watkins, Van Gelder en Frias (2009) in hulle bespreking van dankbaarheid na Gerrish (2002) se boek oor Calvyn se opvatting van die Eucharistie wanneer hulle aanvoer dat groot momente in die geskiedenis gefokus was op dankbaarheid: 'For example, Gerrish argued that the reformation theologies of Luther and Calvin were primarily Eucharistic - theologies that focused on grace and gratitude' (Watkins et al. 2009:438).

Dit is nie moeilik om 'n mens te verbeel dat in die praktyk waar 'n groot gedeelte van die ritueel gewy kan word aan

2.Mens moet in die bespreking van die deugde en goeie karaktertrekke hier onder ten minste twee voorbehoude in ag neem: Die eerste is dat die deugde wat Peterson en Seligman (2004) identifiseer, kwalik meer as heuristise hulpmiddels is wat help om die goeie karaktertrekke 'n mate van orde te gee (Collicutt 2015:57). Of soos Peterson en Park (2011:27) dit self stel: '... the hierarchical organization - strength under virtues - is a conceptual scheme and not a hypothesis to be tested with data". Die ander voorbehoud is op' $n$ manier voor die hand liggend: verskillende teoreties Die ander voorbehoud is op " $n$ manier voor die hand liggend: verskillende teoretiese en wetenskaplike konsepte kan nie noodwendig op dieselfde manier in di onderskeie dissiplines gebruik word nie. Dit is natuurlik ook die geval van die teologiese inhoud van die deugde in Aquinas soos wat dit hier in ontvangs geneem is, die hantering van die deugde en die goeie karaktertrekke in die Positiewe Sielkunde. Dit hoef natuurlik nie ' $\mathrm{n}$ probleem te wees nie en die teoretiese konsept van die Positiewe Sielkunde kan as voorbeeld die refleksie oor en praktyk van iets soos die viering van die Eucharistie verryk. 'n dankgebed, sal bydra om dankbaarheid by mense te kweek nie.

\section{Praxis}

Laastens beklemtoon die deugde-etiek die rol van praktyke binne 'n gemeenskap om karakter te vorm.

Die Positiewe Sielkunde stel ook hul eie stel praktyke voor wat reeds geïmpliseer word in die praktyk van die Eucharistie (die benaming natuurlik afgelei van die Griekse woord wat beteken om dank te betuig). Die goeie karaktertrek van Peterson en Seligman (2004) waarna ons verwys het, is dankbaarheid, en dit is tog vir my interessant dat Scott Barry Kaufman (2015) in 'n studie wat hy onderneem het om te bepaal watter goeie karaktertrek die grootste bydrae maak tot welstand (in Seligman se sin van die woord) gevind het: 'The single best predictor of well-being was gratitude'.

In een van die formuliere uit die NG Kerk se handleiding vir die erediens word daar samevattend oor die betekenis van die Nagmaal gesê: 'Uit dit alles blyk duidelik dat die nagmaal ten slotte 'n fees van dankbaarheid is' (NG Kerk 2010:89).

Die breë ekumenies liturgiese voorstel van die viering van die nagmaal, soos dit aangebied word in die eredienshandleiding, beklemtoon 'n praktyk; die praktyk van dankbaarheid wat die Positiewe Sielkunde sal ondersteun: 'Here, ons God, dit is reg en goed dat ons ons dank aan U bring. Dit is ons plig om dit altyd en oral te doen, deur Jesus Christus ons Here'.

Die praktyk van dankbaarheid wat Seligman aanbeveel is die drieseëninge-oefening (Seligman 2011:33), waar dit die gedagte is om aan die einde van die dag drie dinge neer te skryf wat goed gegaan het en waarom dit goed gegaan het.

'n Ander oefening wat Seligman (2011) aanbeveel, is wat genoem word 'active, constructive responding'. Hy skryf:

People we care about often tell us about a victory, a triumph, and less momentous good things that happen to them. How we respond can either build the relationship or undermine it. (bl. 48)

Aktiewe konstruktiewe reaksie behels dat mens met aandag luister wanneer iemand vir jou goeie nuus vertel, en dat jy met entoesiasme die persoon sal aanmoedig om die gebeurtenis te laat herleef (Seligman 2011:50).

Hierdie praktyk sou met relatiewe gemak in 'n klein eucharistiese byeenkoms geïnkorporeer kon word. Daar sou byvoorbeeld nie net na die 'leed' in die afkondigings en voorbidding aandag geskenk kon word nie, maar veral ook aan die 'lief'. Daar sou entoesiasties en verbaal tydens die 'afkondigings'-geleentheid van die liturgie aandag daaraan gegee kon word.

Hierdie baie onvolledige gesprek oor die deugdelike vormingkrag van die Eucharistie vanuit die Teologie en die Sielkunde is net bedoel om illustratief te wees - die verskillende praktyke en sterk punte van die Positiewe 
Sielkunde sou op kreatiewe wyses ook met die viering van die Eucharistie in verband gebring kon word.

\section{Die presterende lewe en die viering van die Eucharistie}

Dis tog vir my opmerklik dat Scheib (2014) in haar artikel nie die laaste gedeelte van Seligman se 'PERMA'-model, naamlik prestasie, bespreek nie.

Sy verskaf nie 'n rede vir hierdie weglating nie, maar 'n mens kan spekuleer dat, ofskoon aspekte soos positiewe verhoudings, betekenis, en selfs positiewe emosie binne 'n pastoraal teologiese register sinvol kan wees, dit dalk moeiliker is om ruimte te vind vir prestasie wat beskou word deur Seligman dat dit 'is often pursued for its own sake, even [if] it brings no positive emotion, no meaning, and nothing in the way of positive relationship' (Seligman 2011:Kindleuitgawe, plekmerker 403). Dit kan gesien word as prestasie wat dikwels ter wille van sigself nagestreef word, selfs al bring dit nie positiewe emosie, betekenis of groei in verhoudings nie.

Seligman is duidelik daaroor dat dit selde is dat die presterende lewe in 'n suiwere vorm gevind word, maar dit is tog vir hom belangrik om te erken dat prestasie ' $n$ duidelike en onderskeibare element van welstand is, en dat mense dié soort lewe ter wille van sigself kies (2011:Kindleuitgawe, plekmerker 422). Hierdie dimensie is ook vir Seligman tekenend daarvan dat hy die taak van die Positiewe Sielkunde as beskrywend en nie voorskriftelik sien nie (2011:plekmerker 433).

In my eie nadenke, nog voor ek Scheib (2014) se artikel teëgekom het, het ek ook geworstel oor wat ek met hierdie dimensie van Seligman se konstruk en die viering van die Eucharistie moet maak.

Wat dié aspek betref, kan mens reflekteer oor die rol wat genade in die deugsame lewe speel. Soos wat Beier (2014) dit stel: 'PP argues that we can pull ourselves up existentially by our boot straps ...'. Die manier waarop Beier (2014:5) die Positiewe Sielkunde verduidelik, is dat die Positiewe Sielkunde 'n soort sielkunde is wat mens geregtig laat voel op 'positiewe' emosies wat die byproduk van ervarings van bevrediging is, wat gebaseer is op die uitoefening van goeie karaktertrekke en deugde.

Beier (2014:4) is reg dat die uitleef van die deugde die weg na welsyn is vir die Positiewe Sielkunde, en in die loop van dié studie het ek tot dieselfde gevolgtrekking gekom. Die weg hoef egter nie sonder genade te wees nie - en die deelname aan die Eucharistie is vir my die bevestiging daarvan.

Dit is hier waar die teologiese bydrae van Aquino aangaande die deugde 'n rol kan speel. In 'n artikel oor die samehang tussen Aquino se morele en sakramentele teologie kom Harmon (2009:469) tot die gevolgtrekking dat '... (t)he theological virtues perfect the soul and its powers by making man's actions adequate to the attainment of God as his end'. Hierdie deugde is gawes, in die sin dat die mens nie in staat is om sulke deugde te verdien of te kweek nie. Dit kan alleen deur genade ontvang word. Dit is egter nie die geval, volgens Harmon (2009), dat die teologiese deugde die natuurlike mens agterlaat nie, maar eerder dat dit die natuurlike mens vervolmaak. Die genade van die teologiese deugde vloei deur die mense se hele wese met die effek dat dit die mens verhef en homself of haarself geskik maak om sy of haar hoogste doel te bereik.

Eweneens is die kernklem wat op die Eucharistie geplaas kan word dat dit 'n geskenk van God aan ons is. Dit is God wat handel in die sakramente (Wolterstorff 1998:311), eerder as dat die klem gelê word op die feit dat ons ons eksistensiële 'sokkies moet optrek'. Daardeur kan dié perspektief ook beklemtoon word, of, in die taal van die gewoontes en deugde, kan die klem volgens Aquino gelê word op die feit dat die deugde ingegiet word. Die lewe van aanbidding, volgens Dunnington (2011), die lewe wat gesentreer is rondom die Eucharistie, is nie een waarin ons self moet regkom nie, maar eerder:

Worship of the triune God releases us from the need to justify ourselves through strategies of self-deception by continually revealing that we are justified by Christ alone. And worship of the triune God relieves us of the burden of achieving our own identity and sustaining our own story by drawing us, through the work of the Spirit, into the life of God. (Dunnington 2011:Kindle-uitgawe plekmerker 1806)

As die prestasie wat ons wil bereik, is om deel te neem aan die lewe van God, en om 'n deugsame lewe te lei waar ons lewe gerig word op 'n lewegewende praktyk, dan kan die viering en deelname aan die Eucharistie op sigself 'n 'prestasie' wees.

\section{Slot}

Barnard en Wepener (2012:3) voer aan dat die liturgie moet bydra tot menslike florering. As mens hierdie stelling as waar aanvaar en as jy Seligman se teorie van welstand aanvaar as 'n nuttige omskrywing en operasionalisering van menslike florering, kan Seligman se vyf komponente van welstand 'n nuttige lens wees waardeur gesien kan word dat die viering van die Eucharistie bydra tot die volheid van die lewe.

Radcliffe (2008) se beskrywing van die Eucharistie is 'n gepaste klink van die wynglas:

... the Eucharist is indeed a drama; it enacts the fundamental drama of all human existence. It forms us as people who believe, hope and have charity. These are usually called 'the theological virtues'. They are 'theological' because they are a sharing in God's life. Faith, hope and charity are ways in which God makes his home in us, and we are at home in God. They are 'virtues' because they touch us with God's virtues, God's dynamic grace, making us strong for our journey to happiness in God. (Kindleuitgawe, plekmerker 111) 


\section{Erkenning}

Hierdie artikel is gebaseer op my PhD-verhandeling, getiteld: 'Die weeklikse viering van die Eucharistie en die volheid van die lewe', onder leiding van Prof. Julian Müller.

\section{Mededingende belange}

Die outeur verklaar dat hy geen finansiële of persoonlike verbintenis het met enige party wat hom nadelig of voordelig kon beïnvloed het in die skryf van hierdie artikel nie.

\section{Outersbydrae}

Ek is die enigste outeur van hierdie artikel. Dit is gebaseer op my PhD-verhandeling, getiteld: 'Die weeklikse viering van die Eucharistie en die volheid van die lewe' onder leiding van Prof. Julian Müller.

\section{Etiese oorwegings}

Hierdie artikel volg alle etiese standaarde vir navorsing sonder direkte kontak met mens of dier.

\section{Befondsing}

Die outeur het ' $n$ beurs ontvang van die Universiteit van Pretoria om die navorsing te voltooi.

\section{Data beskikbaarheidsverklaring}

Die deling van data is nie van toepassing op hierdie artikel nie, aangesien geen nuwe data in die studie geskep of ontleed is nie.

\section{Vrywaring}

Die menings en opinies wat in die artikelweergegee word, is dié van die outeur(s) en weerspieël nie noodwendig die amptelike beleid of posisie van enige geaffilieerde agentskap van die outeur(s) nie.

\section{Literatuurverwysings}

Barnard, M. \& Wepener, C., 2012, 'Reclaiming space for learning in liturgical contexts: Cracks in the maxim of the uselessness of liturgical ritual', HTS Teologiese Studies/ Theological Studies 68(2), 1-8. https://doi.org/10.4102/hts.v68i2.1184

Beier, M., 2014, 'Always look at the bright side of life? Positive psychology, psychoanalysis, and pastoral theology', The Journal of Pastoral Theology 24(2), 3.1-3.35. https://doi.org/10.1179/jpt.2014.24.2.003

Benedict XVI, 2007, Sacramentum caritatis, viewed 12 November 2015, from http:// books.google.co.za/books?id=KqtIPQAACAAJ\&dq=intitle:SACRAMENTUM+CARIT books.google.co.za/books?id=Kqt
ATIS\&l=\&cd=14\&source=gbs_api.

Billings, J.T., 2007, Calvin, participation, and the gift: The activity of believers in union with Christ, Changing paradigms in historical and systematic theology, Oxford University Press, Oxford.
Caldecott, S., 2012, 'Is life a transcendental?', Radical Orthodoxy: Theology, Philosophy, Politics 1(1\&2), 188-200.

Charry, E.T., 2011, 'Positive theology: An exploration in theological psychology and positive psychology', Journal of Psychology and Theology 30(4), 284-293.

Collicutt, J., 2015, The psychology of Christian character formation, SCM Press, London.

Csikszentmihalyi, M., 1992, Flow: The psychology of happiness, Rider, London. Dunnington, K., 2011, Addiction and virtue, IVP Academic, Downers Grove, IL.

Fredrickson, B.L., 2013, Love 2.0, Hudson Street Press, New York.

Gerrish, B.A., 2002. Grace and gratitude, Wipf \& Stock, Eugene, OR.

Hackney, C.H., 2007, 'Possibilities for a Christian positive psychology', Journal of Psychology and Theology 35(3), 211-221. https://doi.org/10.1177/009164710 703500304

Harmon, T.P., 2009, 'The sacramental consummation of the moral life according to St. Thomas Aquinas', New Blackfriars 91(1034), 465-480. https://doi.org/10.1111/ j.1741-2005.2009.01315.x

Hunsinger, G., 2008, The Eucharist and ecumenism, Cambridge University Press.

Isaacowitz, D.M., Vaillant, G.E. \& Seligman, M.E.P., 2003, 'Strengths and satisfaction across the adult lifespan', The International Journal of Aging and Human Development 57(2), 181-201. https://doi.org/10.2190/61EJ-LDYR-Q55N-UT6E

Kaufman, S.B., 2015, 'Which character strengths are most predictive of well-being?' Scientific American Blog, viewed 08 October 2015, from http://blogs. scientificamerican.com/beautiful-minds/which-character-strengths-are-mostpredictive-of-well-being/.

Lopez, S.J. \& Snyder, C.R., 2011, The Oxford handbook of positive psychology, Oxford University Press, Oxford.

Mcpartlan, P., 1993, The Eucharist makes the church: Henri de Lubac and John Zizioulas in dialogue, T\&T Clark, London.

Montoya, A.F.M., 2009, The theology of food: Eating and the Eucharist, Wiley-Blackwell, Chichester.

NG Kerk, 2010, Handleiding vir die erediens, Bybel-Media, Wellington.

Niemiec, R.M. \& Wedding, D., 2014, Positive psychology at the movies, 2nd edn., Hogrefe Verlag, Boston, MA.

Nyengele, F., 2014, 'Cultivating ubuntu: An African postcolonial pastoral theological engagement with positive psychology', The Journal of Pastoral Theology 24(2) 4.1-4.35. https://doi.org/10.1179/jpt.2014.24.2.004

Oord, T.J., 2010, Defining love, Brazos Press, Ada, MI.

Peterson, C., 2013, Pursuing the good life, Oxford University Press, Oxford, UK.

Peterson, C. \& Park, N., 2011, 'Classifying and measuring strengths of character', in S.J. Lopez \& C.R. Snyder (eds.), The Oxford handbook of positive psychology pp. 25-33, Oxford University Press, Oxford.

Peterson, C. \& Seligman, M.E.P., 2004, Character strengths and virtues: A handbook and classification, Oxford University Press, Oxford.

Radcliffe, T., 2008, Why go to church? Continuum, London.

Scheib, K., 2014, 'All shall be well: Flourishing and well-being in positive psychology and feminist narrative pastoral theology', Journal of Pastoral Theology 24(2) 2.1-2.17. https://doi.org/10.1179/jpt.2014.24.2.002

Scruton, R., 2014, The soul of the world, Princeton University Press, Princeton, NJ. Seligman, M.E.P., 2002, Authentic happiness, Simon \& Schuster, New York.

Seligman, M.E.P., 2011, Flourish, Simon \& Schuster, New York.

Sundararajan, L., 2005, 'Happiness donut: A Confucian critique of positive psychology' Journal of Theoretical and Philosophical Psychology 25(1), 35-60. https://doi. org/10.1037/h0091250

Van Buskirk, G.P., 2012, 'Eucharist as habituative practice in Wesleyan virtue ethics', Doxology: A Journal of Worship 29(1), 19-65.

Von Balthasar, H.U., 2004, Love alone is credible, Ignatius Press, San Francisco, CA. Wainwright, G., 2014, Faith, hope, and love, Baylor University Press, Waco, TX.

Ward, G., 2015, 'Salvation: The pedagogy of affect', Nederduitse Gereformeerde Teologiese Tydskrif 55(Suppl. 1), 1-16.

Watkins, P.C., Van Gelder, M. \& Frias, A., 2009, 'Furthering the science of gratitude', in C.R. Snyder \& S.J. Lopez (ed.), The Oxford handbook of positive psychology, pp. 436-445, Oxford University Press, Oxford.

Westberg, D.A., 2015, Renewing moral theology, Inter Varsity Press, Downers Grove, IL. Wolterstorff, N., 1998, Major themes in the reformed tradition, D.K. McKim (ed.), Wipf \& Stock, Eugene, OR. 